\title{
Thematic review on the slaves' feeding in colonial and imperial Brazil
}

\author{
Gairo Garreto ${ }^{1}$, J. Santos Baptista², Antônia Mota ${ }^{3}$, Mário Vaz ${ }^{4}$
}

${ }^{1}$ Federal Institute of Education, Science and technology of Maranhão, BR (gairo@ifma.edu.br), ${ }^{2}$ Associated Laboratory for Energy, Transports and Aeronautics (PROA/LAETA), Faculty of Engineering, University of Porto, PT (jsbap@fe.up.pt) ORCID 0000-0002-8524-5503, ${ }^{3}$ Federal University of Maranhão, BR (motaufma@gmail.com), ${ }^{4}$ Associated Laboratory for Energy, Transports and Aeronautics (PROA/LAETA), Faculty of Engineering, University of Porto, PT (gmavaz@fe.up.pt) ORCID 0000-0002-6347-9608 https://doi.org/10.24840/978-972-752-260-6_0078-0081

\begin{abstract}
Introduction: Until the end of the nineteenth century, the Brazilian economy was based on slave work. In a historical period of incipient mechanization, the main sources of energy used from the transportation to the activation of the available rudimentary equipment, were of animal origin, among them the Man. The enslaved workers spent their energy performing tasks using, in most cases, only hand tools, such as axes, scythes and hoes. Human strength was the only source of available energy for the more elaborated activities that could not be done by animals. These activities ranged from deforestation to digging, from planting to weeding or harvesting. This research aimed to obtain a detailed and descriptive framework of energy replacement conditions of slave labour, through a review of historical sources and contemporary studies. Methodology: Six databases were searched with timeframe after 2014, as well as original historical documents. A snowballing approach allowed finding references before 2014. The studies were selected without language restrictions. The quantification of energy recovery was done based on quantity, quality and type of served food; the energy value of those foods; and the average of slaves' energy expenditure in rural activities. Results: The searches in the six databases provided initially 36,355 articles. After screening and analysing all this information, 16 were included: 6 articles, 5 books and 5 rare books. DISCUSSION: The selected studies classified slaves' feeding as insufficient to energy replacement, of low quality and classified as bulk feed by the researchers, that is, it consisted of low-quality foods and its preparation was carried out carelessly as regards hygiene, ways of cooking or seasoning. This diet was repeated daily, leading to the occurrence of digestive system diseases. The difference between the average daily energy expenditure and the replacement of this energy using the supply provided by the slave owners, was also significant. The reduction of this difference was fundamental to human labour and was supplied in different ways. A rather usual one was an increase in the regular supply of alcoholic beverages conclusions: The analysed studies suggest the existence of precarious and similar energy replacement conditions, among the slaves in the different regions of Brazil.
\end{abstract}

Keywords: Slavery, Modern slavery, Caloric supply, Caloric expenditure, Occupational safety and health Review.

\section{INTRODUCTION}

The slavery in Brazil remained legalised until 1888 (Lei Aurea" - 13th May 1888). Until then, the slaves were the primary labour force, working in the fields which products were mainly aimed at exportation, such as coffee, sugar and cotton production (Albuquerque, 2006). Life expectancy of the slaves at birth was 30\% lower than that between the free population (Schwartz, 1988) and the mortality rate, due to the hard working conditions, caused a decrease among slaves population about $4,5 \%$ per year, only restored by the importation of new slaves from Africa (Viveiros, 1954). Slave labour, or in similar conditions, continues to be a reality all around the world. However, according to international treaties, agreements, declarations and conventions for the protection of human rights, the precarious conditions in which slave labour develops characterise it as a severe form of violation of these rights (Ramos Filho, 2008). The number of people subject to slavery is estimated at 27 million, being the highest concentration in the Southern Hemisphere (PioVesan, 2006). This work is justified as a first step to study and understand the feeding conditions of Brazilian slave labourers, at a time when slavery was legal, but in a current OSH perspective. It is hoped, with this work, to contribute to raising clues and methodologies to approach and identify this type of situations in the different places of the world where these practices are still a reality. 


\section{METHODOLOGY}

A review was done in the initial phase of this research. Studies on the conditions of agricultural work of the slaves in Brazil from the 18th and 19th centuries were selected. In a first step were selected recent studies addressing directly or indirectly this subject, through the research in the following databases: Science Direct, Scopus, Web of Science, Criminal Justice, Ebsco, Business Source Complete with publication in 2014 or later. In all databases, the same combination of keywords was used: slavery and work. No language restrictions were imposed, and the duplicate references were deleted. In the second step, potentially relevant articles were selected based on titles and abstracts. The complete texts of the selected articles were read in full. The information was extracted by completing a standard form with data pertinent to the study (reference, region of the country, description of the agricultural activity, working day and composition of the supply of beverages quantity and quality of food). The bibliographic references of all the selected articles were then analysed for other works, without distinction of type, date or place of publication. This approach allowed us to consider theses, dissertations, rare books and books (publications dating from the eighteenth and nineteenth centuries). The primary sources and the rare books were the most relevant sources due to their detailed descriptions. In the third and last stage, elements related to the general conditions of energy replacement were collected: quantity and quality of food supplied, the composition of these foods and supply of alcoholic products. Finally, the amount of energy supplied, based on the meals provided to the slaves, was compared with the daily caloric expenditure, calculated according to the reports of the developed activities. The daily energy expenditure was measured based on the standard routine, determined according to the descriptions of the consulted authors. The calculations were done using two recognised methodologies: the table of Classification of metabolic rate levels of ISO 7243/2017 (ISO, 2017) and the Occupational Hygiene Standard (OHS 06) of the Jorge Duprat and Figueiredo Foundation (FUNDACENTRO, 2002).

\section{RESULTS}

The searches in the six databases provided 36,355 articles. The temporal delimitation eliminated 28,498 articles. Another 4,312 were withdrawn because they were not published in peerreviewed journals, and 3,536 were excluded because they were off topic. Based on the references of the nine remaining articles, more 19 papers were pre-selected. After analysing the full text of these $28(19+4)$ records, 16 articles were selected: 6 articles, 5 books. References to the inadequacy and poor quality of food available to enslaved workers are recurrent. The composition of this diet is also described as insufficient, with a predominance of cassava flour, maize and beans. Animal proteins were rare. Alcoholic beverages were provided on a daily basis to supplement the calorie replacement or as a stimulant.

\section{DISCUSSION}

Caloric Supply

Although they were the driving force behind the plantations and represented the most significant resources of rural properties, slaves were poorly fed. The studies refer to the feeding of slaves as insufficient for the necessary energy replacement. In addition, it consisted of bad 
quality food and its confection was carelessly carried out in relation to hygiene, cooking or seasoning. To make matters worse, the daily diet was almost always the same, which led to the occurrence of diseases in the digestive system (Eugenio, 2015). It was considered as ideal the diet prescribed to the slaves of Public Finance by the Decision no 151 of August 25, 1829 (Chaia \& Lisanti, 1974). By this rule, a daily portion of $344 \mathrm{~g}$ of dried beef ( $1077 \mathrm{kcal})$ or $459 \mathrm{~g}$ of fresh meat (987 kcal) should be available daily to the Treasury slaves; $29 \mathrm{~g}$ of salt pork meat (202kcal); $83 \mathrm{~g}$ of beans ( $269 \mathrm{kcal}) ; 255 \mathrm{~g}$ of cassava flour $(930,75 \mathrm{kcal})$. The diet should offer a total energy replacement of $2479 \mathrm{kcal}$. The underfeeding of slave population as a common practice among landowners was accompanied by the regular supply of alcoholic beverages as a form of caloric supplementation (Guzman, 2013). This practice was so widespread that, at the beginning of the nineteenth century, the rate of alcohol dependents among the slave population was estimated at $6.75 \%$ (Lima, Oliveira and Santos 2016).

\section{Caloric Expenditure}

In order to calculate the energy consumption, the daily routine of the slaves was divided by the main developed activities: (a) 12 hours of work with high metabolic rate, in the plantations; (b) 1 hour of low metabolic rate activities during meals; (c) 1 hour of moderate metabolic rate activities in the field trips; (d) 3 hours of moderate metabolic rate activities, developed at night; (e) 7 hours of rest or sleep. The total energy expenditure corresponding to the activities described (a, b, c, d, e) corresponds to $5935.5 \mathrm{kcal}$ per day, adopting the methodology of ISO 7243: 2017 (ISO, 2017). This sum results in $6625 \mathrm{kcal}$ per day if the calculation is performed by the Occupational Hygiene Standard - NHO 06, whose methodology was developed in Brazil by FUNDACENTRO. Accordingly, there is a significant difference between the average daily energy consumption by the slave and the replacement of that energy by its owners. However, the reduction of this difference was fundamental so that the work could be carried out, and was done in different ways. The most usual was an increase in the regular supply of alcoholic beverages (Pinsky, 1988).

\section{CONCLUSIONS}

In the nineteenth century, the general conditions of slave feeding in Brazil showed a significant difference between the energy consumed in the required daily activities and what was offered for its replacement. The two diets considered ideal by the slave owners were analysed, and their energetic values calculated. However, comparing the energy supplied with the estimated energy expenditure in the daily routine of a farm slave, these diets presented a very significant difference. In order to guarantee the necessary energy, a supplement was provided consisting of alcoholic beverages, sugar derivatives and pig fat. However, even with the supply of these high energy products, it was imperative that the diet is supplemented with the foods they could produce in the individual plantations they were forced to keep in the few moments allowed by the work routine. The general energy recovery conditions analysed were similar regarding the composition and quality of the offered diets and the energy expenditure in the planting activities throughout Brazil. 


\section{Acknowledgements}

The authors would like to thank the support of Fundação de Amparo à Pesquisa e ao Desenvolvimento Científico e Tecnológico do Maranhão (FAPEMA) / Secretaria de Estado da Ciência, Tecnologia e Inovação (SECTI) and Governo do Estado do Maranhão for funding this research.

\section{References}

Albuquerque, W. R. d. (2006). Uma história do negro no Brasil. Brasília: Fundação Cultural Palmares. ISBN: 85-88070022.

Chaia, J., \& Lisanti, L. (1974). O escravo na legislação brasileira (1808-1889). Revista de História. ano XXV, 49(99), 241248. DOI: 10.11606/issn.2316-9141.rh.1974.132589.

Lima, P. V. S. F., de Oliveira, K. A., \& dos Santos, D. L. R. (2016). Aspectos gerais da saúde dos escravos no Brasil: revisão de literatura. Gestão e Saúde, 7(1), pp. 471-489. DOI: 10.18673/gs.v7i1.22093

Eugenio, A. (2015). Luis Gomes Ferreira reports on the health of slaves in his work entitled Erärio mineral (1735). Historia, Ciencias, Saude - Manguinhos, 22(3), 881-897. doi:10.1590/\$0104-59702015000300013

FUNDACENTRO, F. J. D. F.-. (2002). Taxa Metabólica Por Tipo de Atividade. In. Brasília: Ministério do Trabalho. URL: http://www.fundacentro.gov.br/biblioteca/normas-de-higiene-ocupacional/publicacao/detalhe/2013/3/nho-06avaliacao-da-exposicao-ocupacional-ao-calor

Guzmán, R. A. F. (2013). The feeding of slave population in the United States, the caribbean, and Brazil: Some remarks in the state of the art. America Latina en la Historia Economica, 20(2), 5-35. DOI: 10.18232/alhe.v20i2.537.

ISO, I. O. f. S.-. (2017). Classificação dos níveis de taxa metabólica (ISO 7243/2017). In. Genebra: ISO.

NEPA, N. d. E. e. P. e. A. (2006). Tabela Brasileira de Composição de Alimentos - TACO. In (2nd ed.). Campinas - SP: Unicamp. URL: http://www.nepa.unicamp.br/taco/tabela.php?ativo=tabela.

Pinsky, J. (1988). Escravidão no Brasil (7 ed.). São Paulo: Contexto. ISBN: 978-8506071571

PioVesan, F. (2006). Trabalho escravo e degradante como forma de violação aos direitos humanos. In: Velloso, Gabriel; Fava, Marcos Neves [Coord.].Trabalho escravo contemporâneo: o desafio de superar a negação. São Paulo: LTr, 151-165. ISBN: 8536108754

Ramos Filho, W. (2008). Trabalho degradante e jornadas exaustivas: crime e castigo nas relações de trabalho neoescravistas. Revista Direitos Fundamentais \& Democracia, 4(4). URL: http://revistaeletronicardfd.unibrasil.com.br/index.php/rdfd/article/view/213

Schwartz, S. B. (1988). Segredos Internos: Engenhos e escravos na sociedade colonial 1550-1835 (L. T. Motta, Trans.). São Paulo: Companhia das Letras. ISBN:9788571640122.

Viveiros, J. d. (1954). História do Comércio do Maranhão, 1612 - 1895. São Luís: Associação Comercial do Maranhão. URL: http://memoria.org.br/pub/meb000000461/histcomvol2mar/histcomvol2mar.pdf 